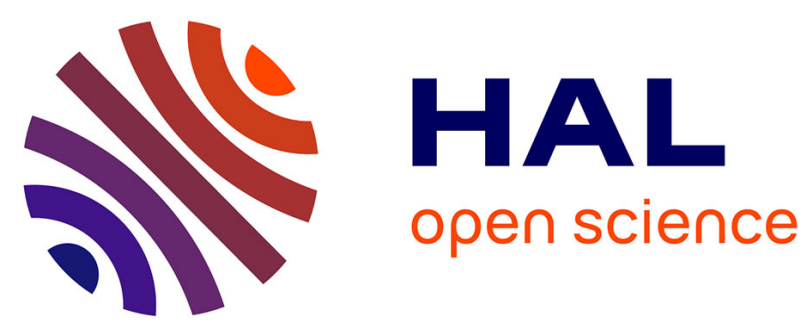

\title{
Impacts of new agricultural practices on soil erosion during the Bronze Age in the French Prealps
}

Jérémy Jacob, Jean-Robert Disnar, Fabien Arnaud, Emilie Gauthier, Yves Billaud, Emmanuel Chapron, Gérard Bardoux

\section{- To cite this version:}

Jérémy Jacob, Jean-Robert Disnar, Fabien Arnaud, Emilie Gauthier, Yves Billaud, et al.. Impacts of new agricultural practices on soil erosion during the Bronze Age in the French Prealps. The Holocene, 2009, 19 (2), pp.241-249. 10.1177/0959683608100568 . insu-00311633

\section{HAL Id: insu-00311633}

https://hal-insu.archives-ouvertes.fr/insu-00311633

Submitted on 19 Aug 2008

HAL is a multi-disciplinary open access archive for the deposit and dissemination of scientific research documents, whether they are published or not. The documents may come from teaching and research institutions in France or abroad, or from public or private research centers.
L'archive ouverte pluridisciplinaire HAL, est destinée au dépôt et à la diffusion de documents scientifiques de niveau recherche, publiés ou non, émanant des établissements d'enseignement et de recherche français ou étrangers, des laboratoires publics ou privés. 


\title{
Impacts of new agricultural practices on soil erosion during the Bronze Age in the French Prealps
}

\author{
Jérémy Jacob $^{1 *}$, Jean-Robert Disnar ${ }^{1}$, Fabien Arnaud ${ }^{2}$, Emilie Gauthier ${ }^{3}$, Yves Billaud ${ }^{4}$, \\ Emmanuel Chapron ${ }^{1}$, Gérard Bardoux ${ }^{5}$.
}

1. Université d'Orléans, CNRS/INSU, Université François Rabelais Tours, Institut des Sciences de la Terre d'Orléans (ISTO), UMR 6113, Campus Géosciences, 1A rue de la Férollerie, 45061 Orléans cedex 2, France.

2. EDYTEM, UMR 5204 du CNRS/Université de Savoie, Campus Savoie Technolac, F73376, le Bourget du Lac, France.

3. Laboratoire de Chrono-écologie, UMR 6565/CNRS, UFR Sciences, 16 route de Gray, 25030 Besançon cedex, France.

4. Ministère de la Culture, DRASSM 58 bis rue des Marquisats 74000 Annecy, France.

5. BIOEMCO, UMR 7618 du CNRS/INRA Centre de Versailles-Grignon, Bâtiment EGER, FR-78850 Thiverval-Grignon, France.

\footnotetext{
* Corresponding author e-mail address : jeremy.jacob@univ-orleans.fr (J. Jacob)
} 


\begin{abstract}
In order to better understand the evolution of past climate-human-environment interactions in the North-western Alps during the Holocene, we have analysed the lipid content of two cores taken from the sediments of Lake le Bourget (French Alps). By using a specific molecular biomarker of Panicum miliaceum (broomcorn millet) previously defined and a new molecular marker of soil erosion, we demonstrate that the onset of millet cultivation coincides with the onset of major soils erosion in the catchment during the Middle Bronze Age. Although archaeological and archaeobotanical investigations indicate a discrete human occupation of the lakeshores at this period, they also point to a regional change in agricultural practices that deeply affected soils. The evolution of millet cultivation appears in strong connection with climatic variations, estimated in the same cores from the variations in titanium, a proxy of hydrological changes in the region. Social and cultural triggers cannot be discarded at this stage. Such an approach applied to more sedimentary archives shows high potential to unravel the temporal and spatial dynamics of human land-use.
\end{abstract}

Keywords: Agriculture, Panicum miliaceum, Land Use, Bronze Age, Biomarkers, Lake Sediments. 


\section{Introduction}

The discrimination between anthropic and climatic triggers on the past evolution of continental surfaces entails the establishment of high resolution records based on specific tracers of climate parameters (e.g. temperature, precipitation), ecosystems modifications (vegetation, physico-chemical conditions) and human activities (e.g. land use). Mountainous ecosystems are especially sensitive to climate changes and are more likely to be the first that would be affected by a probable "Global Change”. Previous work revealed that Lake Le Bourget sediments (French Prealps, Figure 1) constitute high resolution archives of the paleohydrological changes that affected the Alps during the Holocene (Chapron et al., 2002; 2005; Arnaud et al., 2005; Revel-Rolland et al., 2005). Indeed, Rhône River floods carry an allochthonous detrital fraction into Lake Le Bourget through the Savière canal and the Chautagne swamp (Figure 1) that is significantly distinct from the authigenic carbonate fraction. Hence, the frequency of Rhône River floods, which is connected to the precipitation regime over the Alps, can be unravelled from high proportions of detritic elements, such as titanium, in the sediments (Arnaud, 2003; Revel-Rolland et al., 2005). Nevertheless, critical questions remain on the possible human impacts that would bias the detritic signal up to now interpreted as purely climatic. Lake Le Bourget is rich in archaeological sites that range from the Neolithic up to Mediaeval times (Marguet, 2002; Billaud and Marguet, 2005). Archaeobotanical data acquired on a lake-dwelling site indicate early but moderate impacts of agriculture on land use during the Bronze Age (Bouby and Billaud, 2001). The extent to which these types of settlements and activities modified the landscape and the detrital signal in Lake le Bourget remains an open question.

Numerous studies attest to the potential of molecular markers preserved in lacustrine sedimentary archives for reconstructing past climatic and environmental variability (e.g. Meyers and Lallier-Vergès, 1999; Meyers, 2003; Oldfield et al., 2003; Fisher et al., 2003) 
although few studies report organic molecules that are unambiguously indicative of human activities. Recently, we brought evidences that the miliacin (olean-18-en-3 $\beta$-ol methyl ether, Figure 2) preserved in Lake le Bourget late Holocene sediments originated from broomcorn millet (Panicum miliaceum), an allochthonous plant that was presumably introduced par Man in the catchment (Jacob et al., 2008; Jacob et al., in press). Then, we used the evolution of miliacin concentration in the sediment to infer the onset and the broad evolution of $P$. miliaceum cropping around the lake (Jacob et al., 2008). This finding was of high relevance to palynological approaches that only allow the recognition of a Cerealia type pollen without further discrimination. This molecular approach would also allow attesting to the presence of a cultivated plant where pollen grains are not preserved, such as in Lake le Bourget deep sediments.

The present work is threefold. It first aims at bringing refining the evolution of millet cultivation during the Bronze Age by measuring miliacin concentrations in another core drilled in the same lake. This is, to our knowledge, an original attempt in comparing palaeoenvironmental signals recovered from molecular biomarkers in two cores drilled in the same lake, at some distance. Secondly, this paper proposes a new molecular biomarker specific of soil erosion: Trimethyl tetrahydrochrysene (TTHC; Figure 2). TTHC is a diagenetic derivative of oleanane-type pentacyclic triterpenes (Wakeham et al., 1980). It is reputed to be produced in leaf litters and soils by microbial alteration of higher plant triterpenoid precursors (Wakeham et al., 1980; Yunker et al., 1995). The comparison of miliacin and TTHC evolution with that of pollen acquired on littoral cores allows us discussing the onset of millet cultivation and its impact on soils within the frame of agricultural developments in Europe during the Bronze Age. 


\section{Settings}

Lake Le Bourget is a foreland lake located in front of the French NW Alps $\left(45^{\circ} \mathrm{N} 45^{\prime}\right.$; 5E 52', $231.5 \mathrm{~m}$ a.s.l., $18 \mathrm{~km}$ long, 2-3 km wide, $146 \mathrm{~m}$ deep). The catchment area is characterized by a local watershed of $600 \mathrm{~km}^{2}$ related to the Leysse and Sierroz rivers. This catchment area extends considerably during major floods of the Rhône River, when its stream flows into lake Le Bourget through its normal outlet, the Saviere channel. (Figure 1).

\section{Materials and methods}

Core LDB01-I (N 4544,848’; E 550,891') was taken in 2001 on the western flank of the northern deep sub-basin of Lake Le Bourget (Figure 1) at $129 \mathrm{~m}$ water-depth, with an UWITEC coring device operated from a barge. Core LDB04-I (N 4547,140’; E 550,440’) was retrieved in 2004, at 106 m depth, using the same device. The sediments deposited at this latter site are assumed to have better recorded the flooding activity of the Rhône River into the lake than core LDB01, taken at more distance from the Rhodanian influence (Chapron et al., 2002; 2005; Arnaud et al., 2005).

A short core was retrieved at the Tresserve archaeological site (Le Saut de la Pucelle, Figure 1), on the eastern side of Lake le Bourget. The sampling and analytical scheme for pollen analyses are presented elsewhere (Magny et al., 2008; Richard and Gauthier, 2007; Gauthier and Richard, submitted).

\section{$\underline{\text { Age models }}$}

The age model of core LDB01 is detailed in Arnaud et al. (2005). The age model for core LDB04 is described in Jacob et al. (2008). The dates used for establishing age models in both cores have been published elsewhere (Chapron et al., 2002; Arnaud et al., 2005; Jacob et al., 2008). They are synthesised in Table 1 and Table 2. The resulting age models for cores 
LDB01 and LDB04 are illustrated in Figure 3. The 6-7 m interval in core LDB04 corresponds to a section that was disconnected from the rest of the core during coring process.

Two ${ }^{14} \mathrm{C}$ dates acquired at the base of the Tresserve core indicate that it reached sediments deposited during the Early Bronze (1880-1680 and 1920-1680 BC). The transition from Middle to Late Bronze Age is estimated from a combination of sedimentological and archaeological evidences. Laid woods collected at ca. $20 \mathrm{~cm}$ were dendrochronologically dated from the Final Bronze Age (931-825 BC). The transition from the Bronze Age to the First Iron Age is documented by a drastic decrease of anthropogenic indicators (see below). Although these elements do not allow constituting a precise age model, they are satisfactory for comparing the Tresserve record with that established from LDB04 core.

\section{Lipid analysis}

170 one cm-thick samples of sediment were selected for lipid analyses from the $14 \mathrm{~m}$ long LDB04 core. The sampling interval was $10 \mathrm{~cm}$ throughout the core except in the 2-5 $\mathrm{m}$ section where it was reduced to 3-5 cm. 25 samples were selected from core LDB01 within the 429-610 cm depth interval that corresponds to the 2250-110 BC time span.

$2 \mathrm{~g}$ of dried sediment were ultrasonically extracted three times with a mixture of dichloromethane:methanol (1:1 v/v). After centrifugation, the supernatants were combined and dried under nitrogen. The total lipid extract was then separated into acidic and neutral compounds on aminopropyl bounded silica according to Jacob et al. (2008). After addition of $5 \alpha$-cholestane (internal standard), the neutral fraction was analysed by Gas ChromatographyMass Spectrometry using a ThermoFinnigan TRACE-PolarisGCQ equipped with an AS 3000 autosampler as described in Jacob et al. (2008).

Due to possible coelutions with other compounds, the concentrations of miliacin and 3,3,7-trimethyl-1,2,3,4-tetrahydrocrysene (TTHC) were estimated by measuring the areas of 
their peaks on the $\mathrm{m} / \mathrm{z} 189+204+218$ and $\mathrm{m} / \mathrm{z} 218+274$ ion specific chromatograms, respectively. Miliacin concentrations were calculated using an external authentic standard (courtesy of Pr. R. Smith, Loughborough University, UK). TTHC was identified by comparing its mass spectra with published data (Wakeham et al., 1980). TTHC concentration was estimated after calculating a correction factor between the peak area on the ion specific chromatogram and the peak area on the Total Ion Current (TIC), and then reported to the area of the $5 \alpha$-cholestane peak on the TIC.

The carbon isotopic composition of TTHC was measured as described in Jacob et al. (in press). Briefly, the neutral fractions of eleven sediment samples dated back to the Bronze Age were combined and submitted to further fractionation. TTHC was recovered in the same fraction as miliacin. The $\delta^{13} \mathrm{C}$ of TTHC was measured in the same run as miliacin by using GC-C-IRMS with conditions previously defined (Jacob et al., in press).

\section{$\underline{\text { Titanium analysis }}$}

Bulk titanium (Ti) concentrations were measured along the core at $1 \mathrm{~cm}$ spacing with a profiling XRF core scanner at the University of Bremen. Ti is given as counts per seconds. 


\section{Results}

\section{$\underline{\text { Origin of TTHC }}$}

The $\delta^{13} \mathrm{C}$ of TTHC extracted from Lake le Bourget sediments is - $40 \%$. Assuming that the $\delta^{13} \mathrm{C}$ of aromatic diagenetic derivatives of pentacyclic triterpenes is only depleted by 1.5 to $4 \%$ with regard to their precursor (Freeman et al., 1994), a $\delta^{13} \mathrm{C}$ of about $37 \%$ is expected for the compound from which TTHC derives. This value is significantly different from the $\delta^{13} \mathrm{C}$ of miliacin of Lake le Bourget sediments (-23\%; Jacob et al., in press). This difference in carbon isotopic composition allows us excluding any genetic relationship between these compounds (such as TTHC deriving from miliacin) despite their structural analogies.

\section{$\underline{\text { Evolution of titanium, miliacin and TTHC in core LDB04 }}$}

The depth evolution of titanium, miliacin and TTHC in core LDB04 is reported in Figure 4 for the 2000 AD/ 6000 BC time interval. Titanium concentrations in the sediment remain around 200 Cps from 6000 to 2200 BC. The 3600-2200 BC time period corresponds to an interval affected by a slump deposit (cf. Chapron et al., 2005) and by a sedimentary hiatus due to coring operations that both prevented the establishment of a detailed age-depth model for this section. Consequently this time interval will not be discussed further. Ti concentrations reach up to 400 Cps during the 2200-1800 BC and 800-550 BC time intervals. The 550 BC-900 AD time period is characterized by varying titanium values in the 200-400 Cps range with maximum values reaching 1000 Cps in some levels (i.e. at ca. 600 AD). Low Ti values around 900 AD (200 Cps) are followed by an increasing trend towards 1000 Cps around 1300 AD before decreasing down to the Present.

The first appearance of miliacin is noted at ca. 1700 BC. Its concentration levels remain lower than $20 \mathrm{ng} / \mathrm{g}$ during the 1700-1400 BC interval and suddenly increase up to a 
maximum of $200 \mathrm{ng} / \mathrm{g}$ around $850 \mathrm{BC}$. The drastic decrease recorded at $800 \mathrm{BC}$ leads to miliacin concentrations ranging between 20 and 50 ng/g. They are followed by notable and varying concentrations between 80 and $400 \mathrm{ng} / \mathrm{g}$ until $800 \mathrm{AD}$. After this date, miliacin is still detected in Lake le Bourget sediments, but always at levels below $50 \mathrm{ng} / \mathrm{g}$.

TTHC concentrations are lower than 200 ng/g from 6000 to 1700 BC. After this date, TTHC levels first increase dramatically and then exhibit a strong variability in the 100-1000 ng/g range up to the Present.

Compared evolution of miliacin and TTHC in LDB04 and LDB01 during the Bronze Age

In both cores miliacin appears at ca. $1700 \mathrm{BC}$ and its concentrations remain lower than $20 \mathrm{ng} / \mathrm{g}$ up to $1500 \mathrm{BC}$ (Figure 5). Then, its concentrations increase to reach a maximum between 900 and 800 BC (represented by a single sample in core LDB01). before decreasing down to values lower than $100 \mathrm{ng} / \mathrm{g}$ after $800 \mathrm{BC}$.

In contrast to miliacin, TTHC is present in the sediments before $1700 \mathrm{BC}$, but only at low levels (namely < 500 ng/g and 200 ng/g in cores LDB01 and LDB04, respectively). From this date TTHC concentrations increase strongly in both cores and then remain above the concentration levels recorded prior to $1700 \mathrm{BC}$ (Figure 5).. Although some differences are noted in the evolution of miliacin and TTHC in both records, probably imputable to unidentified local factors, the main features (appearance of miliacin at $1700 \mathrm{BC}$, simultaneous increase in TTHC and decrease in miliacin after $800 \mathrm{BC}$ ) attest to their significance at a catchment-scale and points out the consistency of the age models in both cores.

\section{$\underline{\text { Pollen indicators at the Tresserve archaeological site }}$}

The variations of pollen anthropogenic indicators (pollens of Cerealia type, footpath, ruderal and weed communities and Poaceae; Behre, 1981; Berglund and Ralska- 
Jasiewiczowa, 1986) recorded at the Tresserve site, are shown in Figure 6 together with the variations in Fagus pollen percentages and the total percentages of tree pollens (Magny et al., 2008). A notable human impact in the region is recorded since the Early Bronze Age (between 100 and $70 \mathrm{~cm}$ ), attesting to a continuous but discreet human impact in the region since this period. Lower values of anthropogenic indicators recorded during the second part of the Middle Bronze Age (from 60 to $40 \mathrm{~cm}$ ) are interpreted as a lower human presence at this time and are in agreement with a woodland regeneration as attested by an increase in tree pollens (Richard and Gauthier, 2007; Magny et al., 2008; Gauthier and Richard, submitted). The strong increase in palynological anthropisation indices recorded at 931-825 BC at the Tresserve archaeological site (Figure 6) is attributable to the overrepresentation of anthropogenic indicators since the site was effectively occupied during this period. Forest pollen indicators such as Fagus show high values at the end of the Middle Bronze Age and at the beginning of the Late Bronze Age and during the Iron Age. 


\section{Discussion}

\section{Early introduction of $P$. miliaceum around Lake le Bourget}

The scarcity of data concerning the first record of $P$. miliaceum in archaeological sites, mostly based on microfossil remains and charred seeds, does not yet allow defining the precise timing of its domestication and the exact routes of its diffusion.

The first indices of millet agriculture in the Far East were dated back to the Early Neolithic $\left(6^{\text {th }}-7^{\text {th }}\right.$ millennium cal BC), but experimentations may have been conducted earlier in Asia (12,000 BP; see Pechenkina et al., 2005). Panicum miliaceum, as well as Setaria italica (foxtail millet), were cultivated as early as ca. 6000 BC in Northern China/Inner Mongolia and in the Yellow River basin by 5500 BC (Fuller, 2007). P. miliaceum remains were also detected at sites dated back to the $6^{\text {th }}$ and $5^{\text {th }}$ millennium BC in the Caucasus and Eastern Europe, around the Black Sea (Lisitsina, 1984). The apparent synchronicity of $P$. miliaceum primodomestication on both sides of the Eurasian steppes (Marinval, 1995; Zohary and Hopf, 2000; Weber and Fuller, in press) raises several important concerns that are out of the scope of this paper.

P. miliaceum was not introduced in Europe as part of the "Near East Package" of cereals that arrived from the Fertile Crescent. It appeared in Eastern and Central Europe (Ukraine, Moldavia, Czechoslovakia, Southern Poland, Eastern Germany and Austria) during the $5^{\text {th }}$ millennium BC (Zohary and Hopf, 2000; review in Köhler-Schneider and Caneppele, 2007) but whether these finds represent $P$. miliaceum as a cultivated cereal or a weed is debated. Together with S. italica, it spread towards Western Europe and reached Western Germany at the beginning of the $4^{\text {th }}$ millennium (Rösch, 1998). In Northern Italy, $P$. miliaceum cultivation might have started during the Early Bronze Age since remains were detected in Monte Covolo (Pals and Vorrips, 1979) and in Canár (Castiglioni et al., 1998; 
Castelletti et al., 2001), and then in the Terramara di Montale site dated back to the MiddleLate Bronze Age (1650-1200 BC; Mercuri et al., 2006).

The oldest record of P. miliaceum in France (Fossé, Loire et Cher) dates back to 3500 BC (cited in Marinval, 1995). Around Lake le Bourget, $P$. miliaceum remains were first identified at the La Motte-Servolex archaeological site (2000 BC; Netolitzky, 1914), although this old discovery must be taken with caution (Marinval, 1995). At the Grésine site (905-869 BC), high abundances of $P$. miliaceum seeds and chaffs attest to a large consumption in the lake area during Late Bronze Age (Bouby and Billaud, 2001). Hence, the first appearance of miliacin in Lake le Bourget sediments around $1700 \mathrm{BC}$ is in general agreement with the known timing of $P$. miliaceum arrival in Western Europe.

\section{Cultivation and land use during the Bronze Age}

The appearance of miliacin coincides with a drastic increase in TTHC concentration around $1700 \mathrm{BC}$ in both cores. This implies a causal relationship between these two compounds in the sediment, i.e. a strong input of soil-derived TTHC due to millet cultivation. Since, according to forest pollen abundances, the environment remained clearly forested at this time (Figure 6), intensive deforestation is unlikely. Conversely, a modification of agricultural practises could have initiated this destabilisation of soils. During the Neolithic, the agricultural system was based on shifting cultivation on slash-and-burn fields and abandoned to the reforestation after four to five years (Rösch, 1998). The establishment of perennial fields with short fallow phases leading to more intense soil erosion during the Bronze Age (Rösch, 1998) most probably favoured the erosion of soils, leading to high concentrations of TTHC in the sediment. In addition, the transition from wooden tools to metal ones must have had a significant impact on the depth and efficiency of ploughing, and hence on soil erosion. 
Only millet cultivation can be traced with our approach since no other tracer of cultivated plant has been evidenced in the studied sedimentary archives. Cereal pollens -that are classically difficult to distinguish from one another- have not even been preserved in Lake le Bourget deep sediments, as no other pollens did. Millet was most certainly cultivated with other cereals or legumes for which we have currently no specific tracer. But our miliacininferred millet cultivation data show that the introduction of this cereal in the vicinity of Lake le Bourget was coincident with a change in agricultural practises. It would hence support a common diffusion scheme for millet and these new practises.

Our data on the first intensive impact of human cropping on landscapes around Lake le Bourget are then compared to several records within the Alps. In Lej da Champfèr and Lej da San Murezzan (Upper Engadine, Swiss Alps), Cerealia type pollen grains were first detected in significant amounts around 1950 BC together with increasing charcoal proportions. They attest to the development of a special vegetation type after forest clearance by burning (Gobet et al., 2003). When comparing Bronze Age sites located in the north (lakes Soppensee and Lobsigensee) and in the south of the Alps (lakes Lagodi Origlio and Lagodi Muzzano), Tinner et al. (2003) showed that the first peaks of cultivation indicators (Cerealia and Plantago lanceolata) occurred around $1750 \mathrm{BC}$ at both sites, with a stronger increase at ca. $1350 \mathrm{BC}$. According to plant macrofossils and geochemical indices monitored on a core drilled in Sägistalsee lake (Bernese Alps, Switzerland; Koinig et al., 2003; Ohlendorf et al., 2003), the onset of deforestation and soil destabilisation occurred around 1750-1550 BC. Evidence for intensive deforestations and landslides are recorded at $1700 \mathrm{BC}$ in the Western Swiss Alps (Lake Schwarzsee, western; Dapples et al., 2002). At Lago Piccolo de Avigliana (Southwestern Alps, Italy), the first intensive land-use phase is dated back to 2100-1650 BC but farming activities (illustrated by increased proportions of Cerealia type pollens) are only 
noted during the 1500-1350 BC period (Finsinger et al., 2006). Palynological evidence (charcoals and Cerealia type pollens) recovered from Lago Lucone (Northern Italy) indicate that the landscape was affected by intense human management during the Early Bronze Age (2200 BC; Valsecchi et al., 2006). Further south in Lago di Mezzano, Sadori et al. (2004) show an increase in human activities during the Early/Midlle Bronze age (3600 BP). Finally, from a sedimentary record in Adriatic, Oldfield et al. (2003) noted an acceleration of mass sedimentation and an increase in terrigenous input reflecting intensive forest clearance by 1650 BC.

These different records point to an increased impact of human influence on ecosystems in the Alps during the Early/Middle Bronze Age that could be linked to an increased demography, a denser settlement and a stronger economical demand from 1950 BC (Bätzing, 1991). The stronger impact on soil erosion cannot be attributed to a larger area cultivated since at this period pollen results indicate the persistence of a dense forest cover. More simply, it could be linked to the arrival of innovative agricultural practises such as the improvement of agricultural tools that allowed ploughing deeper in soils at this period. It is worthwhile noting that these improvements appear closely connected with the arrival of $P$. miliaceum cropping and it is tempting to consider both (agricultural innovation and millet cropping) as part of a "cultural package" that reached the region at this time. Again, the present scarcity of human land use records does not allow defining a precise scheme for the spread or timing of these innovations in the Alps.

\section{Climate-agriculture-land use interactions during the Bronze Age}

P. miliaceum does not require specific climatic conditions since it grows well in intensive heat (hot summers) and severe drought, up to $1000 \mathrm{~m}$ of altitude (Zohary and Hopf, 2000; S. Jacomet, pers. com.). Therefore, the variations in miliacin concentration cannot be 
explained by climatic variations that would directly affect plant growth. Reversely, these variations could result from cultural and societal changes that are, in part, linked with climatic changes.

\section{The Early/Middle Bronze Age}

The onset of millet cultivation and of intensive soil erosion occurs during the Early/Middle Bronze Age at 1700 BC, a period of rather favourable climatic conditions (as attested by low Ti values indicative of lower frequency of Rhône River floods, Figure 4) that followed the more humid climate prevailing during the 2200-1800 BC time period. Although Lake le Bourget surroundings were occupied since the Neolithic, archaeological surveys point to a discrete regional occupation of the lake shores during the Early Bronze Age (1800-1750 BC in Annecy Lake, Billaud and Marguet, 2005).

Low miliacin concentrations are recorded between 1700 and ca. 1500 BC. Although caution must be taken in interpreting subtle variations in molecular marker concentration, these low concentrations could reflect a restricted surface of millet cultivation due to a high water level, or could also attest to a low population density. In the meantime, the rarefaction of anthropisation indices derived from pollen analyses (Figure 6) attests to a lower human impact in the second part of the Middle Bronze Age (from 60 to $40 \mathrm{~cm}$ ) than before (i.e. between 87 and $70 \mathrm{~cm}$ ), in agreement with a increase in forest pollen percentages. Increasing Ti values between 1700 and 1400 BC indicate enhanced Rhône River floods, in agreement with a regional climatic pejoration in the western Alps (Magny, 2004; Magny et al., 2008) that is also detected in Central Europe (Haas et al., 1998; Zolitschka et al., 2003; Tinner et al., 2003). Although low miliacin concentrations recorded in the $1700-1500$ BC period can attest to a low demography, in agreement with the lack of human settlements at this period around Lake le Bourget (Billaud and Marguet, 2005) and a recovery of the forest cover, it could also 
indicate that $P$. miliaceum was tested as a basic crop before its more intense cultivation during the Late Bronze Age (as attested by higher concentrations in miliacin). As a matter of fact, Köhler-Schneider and Caneppele (2007) noted that in Austria "millet had the status of a casual weed among other summer crops, long before it was cultivated itself”. The spike in miliacin recorded at ca. $1500 \mathrm{BC}$ in core LDB01 (Figure 5) could be interpreted as a local increase in $P$. miliaceum cropping due to favourable conditions on the eastern border of the lake.

The transition from the Middle Bronze Age to the Late Bronze Age is characterized by a notable increase of miliacin concentration and of palynological anthropisation indices (Figure 6). These results point to increasing human impacts in the region during the Late Bronze Age, further supported by the numerous archaeological sites dated from this period on the lake shores (Billaud and Marguet, 2005). This increasing impact occurs within a context of climatic amelioration as depicted by a decreasing trend of titanium that attest to lower Rhône River floods frequency and hence lower precipitation over the Alps (Figure 6).

\section{The Bronze Age - Iron Age transition}

The drastic decrease in miliacin concentrations at ca. 800 BC coincides with a decrease in anthropisation indices noted at the Tresserve site (Figure 6). These results are in agreement with the abandonment of the lakeshore by local populations at that time, as attested by dendrochronology data (Billaud and Marguet, 2005). In the meantime, high Ti values indicate a climatic deterioration (Figures 3 and 5) that is also attested by high water levels of lakes in the region (Magny, 2004). This climatic reversal during the 800-400 BC time period is well documented in the region (van Geel and Magny, 2002; Magny, 2004). It is assumed to have mediated the abandonment of lake-dwelling habitats and the decline of agricultural activities. 
It is worthwhile noting that TTHC concentrations do not decrease with decreasing miliacin concentrations at the Bronze Age/Iron Age transition. This would imply that, although agriculture stopped, soils remained unstable. Since the TTHC concentration in the sediment can be affected by many parameters, its varying values in the sediment records and the differences between cores LDB01 and LDB04 must be interpreted with caution and require further work.

\section{Conclusion}

The compared evolution of a specific tracer of millet cropping, a soil erosion marker and other environmental parameters allows us unravelling intimate relationships between climate, human land use and soil erosion around Lake le Bourget during the protohistory. The introduction of cultivated $P$. miliaceum in the watershed coincides with intensive soil erosion due to the coincident appearance of new agricultural practices. Both occurred during a period of discrete human occupation at the end of the Early Bronze Age. After increasing millet cropping during the Late Bronze Age, agricultural activities drastically decreased at the Bronze Age/Iron Age transition as a result of a climatic reversal.

A better understanding of molecular taphonomy aiming at precising the relationships between molecular signals preserved in sediments and original environmental/anthropic conditions will undoubtedly greatly improve our comprehension of the dynamics of human societies in connection to environmental changes.

\section{Acknowledgments}

The authors wish to thank H. Hunt (Cambridge, UK) for precious advices on $P$. miliaceum domestication and diffusion. M. Hatton and A. Durand are acknowledged for 
technical assistance. This work is par of the Aphrodyte project supported by the ECLIPSE programme (CNRS, France). 


\section{References}

Arnaud, F., Revel, M., Chapron, E., Desmet, M. and Tribovillard, N., 2005: 7200 years of Rhône River flooding activity in Lake Le Bourget: a high-resolution sediment record of the NW Alps hydrology. The Holocene 15, 420-428.

Bätzing, W., 1991: Die Alpen: Entstehung und Gefährdung einer europischen Kulturlandschaft. C.H. Beck, Verlag, München.

Behre, K.E., 1981: The interpretation of anthropogenic indicators in pollen diagrams. Pollen and spores 23, 225245.

Berglund, B.E. and Ralska-Jasiewiczowa, M., 1986: Pollen analysis and pollen diagrams. In Berglund, B.E., editor, Handbook of Holocene Palaeoecolgy and Palaeohydrology. John Wiley \& Sons, p. 455-484.

Billaud, Y. and Marguet, A., 2005: Habitats lacustres du Néolithique et de l‘âge du Bronze dans les lacs alpins français: bilan des connaissances et perspectives. In Della Casa, Ph., M. Trachsel, editors, WES'04 - Wetland Economies and Societies. Proceedings of the International Conference in Zurich, 10-13 March 2004. Chronos, Zurich, Collectio Archæologica 3, 169-178.

Bouby, L. and Billaud, Y., 2001 : Economie agraire à la fin de l’âge du Bronze sur les bords du lac du Bourget (Savoie, France). Comptes Rendus de l’Académie des Sciences II A 333, 749-756.

Castelletti, L., Castiglioni, E. and Rottoli, M., 2001: L'agricoltura dell’Italia settentrionale dal neolitico al Medioevo, in: Failla, O., Forni, G. (Eds.), Le piante coltivate e la loro storia. FrancoAngeli, Torino, pp 33-84.

Castiglioni, E., Motella De Carlo, S. and Nisbet, R., 1998: Indagini sui resti vegetali macroscopici. In Balista, C., Bellintani, P., editors, Cañar di San Pietro Polesine. Ricerche archeo-ambientali sul sito palafitticolo. Padusa Quaderni, 2, Centro Polesano di Studi Storici Archeologici ed Etnografici, Rovigo, pp 115-123.

Chapron, E., Arnaud, F., Noël, H., Revel, M., Desmet, M. and Perdereau, L., 2005: Rhône River flood deposits in Lake Le Bourget: a proxy for Holocene environmental changes in the NW Alps, France. Boreas 35, 404415.

Chapron, E., Desmet, M., De Putter, T., Loutre, M.F., Beck, C. and Deconninck, J.F., 2002: Climatic variability in the northwestern Alps, France, as evidenced by 600 years of terrigenous sedimentation in Lake Le Bourget. The Holocene 12, 177-185.

Dapples, F., Lotter, A.F., van Leeuwen, J.F.N., van der Knaap, W.O., Dimitriadis, S. and Oswald, D., 2002: Paleolimnological evidence for increased landslide activity due to forest clearing and land-use since $3600 \mathrm{cal}$ BP in the western Swiss Alps. Journal of Paleolimnology 27, 239-248. 
Finsinger, W. and Tinner, W., 2006: Holocene vegetation and land-use changes in response to climatic changes in the forelands of the southwestern Alps, Italy. Journal of Quaternary Science 21, 243-258.

Fisher, E., Oldfield, F., Wake, R., Boyle, J., Appleby, P. and Wolff, G.A., 2003. Molecular marker records of land use change. Organic Geochemistry 34, 105-119.

Freeman, K.H., Boreham, C.J., Summons, R.E. and Hayes, J.M., 1994: The effect of aromatization on the isotopic compositions of hydrocarbons during early diagenesis. Organic Geochemistry 21, 1037-1049.

Fuller, D.Q., 2007: Contrasting Patterns in Crop Domestication and Domestication Rates: Recent Archaeobotanical Insights from the Old World. Annals of Botany, 1-27.

Gauthier, E. and Richard, H.: Bronze Age at Lake Bourget (NW Alps, France): vegetation, human impact and climatic change. Quaternary International, submitted.

van Geel, B. and Magny, M., 2002: Mise en évidence d'un forçage solaire du climat à partir de données paléoécologiques et archéologiques : la transition Subboréal-Subatlantique. In Richard, H., Vignot, A., editors, Equilibres et ruptures dans les écosystèmes depuis 20000 ans Europe de l'Ouest. Besançon, 18-22 septembre 2000, Besançon, Presses Universitaires Franc-Comtoises, pp. 107-122.

Gobet, E., Tinner, W., Hochuli, P. A., van Leeuwen, J. F. N. and Ammann, B., 2003: Middle to Late Holocene vegetation history of the Upper Engadine (Swiss Alps): the role of man and fire. Vegetation History and Archaeobotany 12, 143-163.

Haas, J.N., Richoz, I., Tinner, W. and Wick, L. 1998: Synchronous Holocene climatic oscillations recorded on the Swiss Plateau and at timberline in the Alps. The Holocene 8, 301-309.

Itô, H., 1934: The chemical investigation of some gramineae oils. J. Fac. Agri. Hokkaido Univ 37, 1-40.

Jacob, J., Disnar, J.R., Arnaud, F., Chapron, E., Debret, M., Lallier-Vergès, E., Desmet, M. and Revel-Rolland, M., 2008: Millet cultivation history in the French Alps as evidenced by a sedimentary molecule. Journal of Archaeological Science, 35, 814-820..

Jacob, J., Disnar, J.R. and Bardoux, G.: Carbon isotope evidence for sedimentary miliacin as a tracer of Panicum miliaceum (broomcorn millet). Organic Geochemistry, in press.

Jacob, J., Disnar, J.R., Boussafir, M., Sifeddine, A., Albuquerque, A.L.S. and Turcq, B., 2005: Pentacyclic triterpene methyl ethers in recent lacustrine sediments (Lagoa do Caçó, Brazil). Org. Geochem. 36, 449-461.

Kohler-Schneider, M. and Caneppele, A., 2007: Late Neolithic agriculture in eastern Austria: archaeobotanical results from sites of the Baden and Jevišovice cultures (3600-2800 BC). Vegetation History and Archaeobotany, in press. 
Koinig, K.A., Shotyk, W., Lotter, A.F., Ohlendorf, C. and Sturm, M., 2003: 9000 years of geochemical evolution of lithogenic major and trace elements in the sediments of an alpine lake - the role of climate, vegetation and land use history. Journal of Paleolimnology 30, 307-320.

Lisitsina, G.N., 1984: The Caucasus - A centre of ancient farming in Eurasia. In van Zeist, W., Casparie, W.A., editors, Plants and Ancient Man. Balkema, Rotterdam, 285-292.

Magny, M., 2004: Holocene climate variability as reflected by mid-European lake-level fluctuations and its probable impact on prehistoric settlements. Quaternary International 113, 65-79.

Magny, M., Peyron, O., Gauthier, E., Rouèche, Y., Bordon, A., Billaud, Y., Chapron, E., Marguet, A., Pétrequin, P., Vannière, B., 2008. Quantitative reconstruction of climatic variations during the Bronze and early Iron ages based on pollen and lake-level data in the NW Alps, France. Quaternary International, in press.

Marguet, A., 2002: Savoie, lac du Bourget. Elaboration de la carte archéologique des gisements du lac du Bourget. In Bilan Scientifique 2000 du DRASSM 26. Ministère de la Culture et de la Communication, Paris, p. 117-137.

Marinval, P., 1995: Données carpologiques françaises sur les Millets (Panicum miliaceum L. et Setaria italica L. Beauv.) de la Protohistoire au Moyen Age. In Hörandner, E., editor, Millet. Actes du Congrès d'Aizenay (1990). Peter Lang, Frankfurt, p. 31-61.

Mercuri, A.M., Accorsi, C.A., Mazzanti, M.B., Bosi, G., Cardarelli, A., Labate, D.,Marchesini, M. and Grandi, G.T., 2006: Economy and environment of Bronze Age settlements - Terramaras - on the Po Plain (Northern Italy): first results from the archaeobotanical research at the Terramara di Montale. Vegetation History and Archaeobotany 16, 43-60.

Meyers, P.A., 2003: Applications of organic geochemistry to paleolimnological reconstructions: a summary of examples from the Laurentian Great Lakes. Organic Geochemistry 34, 261-289.

Meyers, P.A. and Lallier-Vergès, E., 1999: Lacustrine sedimentary organic matter records of late quaternary paleoclimates. Journal of Paleolimnology 21, 345-372.

Netolitzky, F., 1914: Die Hirse auf antiken funden. Sitzungsber. Wiener Akad. Wiss, Math-Nat. Klasse, 123 (I), 725-753.

Ohlendorf, C., Sturm, M. andHausmann, S., 2003: Natural environmental changes and human impact reflected in sediments of a high alpine lake in Switzerland. Journal Paleolimnology 30, 297-306. 
Oldfield, F., Wake, R., Boyle, J., Jones, R., Nolan, S. and Gibbs, Z., 2003. The late-Holocene history of Gormire Lake (NE England) and its catchment: a multiproxy reconstruction of past human impact. The Holocene 13, 677-690.

Oldfield, F., Asioli, A., Accorsi, C.A., Mercuri, A.M., Juggins, S., Langone, L., Rolph, T., Trincardi, F., Wolff, G., Gibbs, Z., Vigliotti, L., Frignani, M., van der Post, K. and Branch, N., 2003: A high resolution late Holocene palaeo environmental record from the central Adriatic Sea. Quaternary Science Reviews 22, 319342.

Pals, J.P. and Vorrips, A., 1979: Seeds, fruits and charcoals from two prehistoric sites in Northern Italy. Archaeo-Physica 8, 217-235.

Pechenkina, E.A., Ambrose, S.H., Xiaolin, M. and Benfer, R.A., 2005: Reconstructing northern Chinese Neolithic subsistence practices by isotopic analysis. Journal of Archaeological Science 32, 1176-1189.

Popova, C. and Bozilova, E., 1998: Palaeoecological and palaeoethnobotanical data for the Bronze Age in Bulgaria. In In the Steps of James Harvey Gaul (James Harvey Gaul in memoriam; Sofia), 391-397.

Revel-Rolland, M., Arnaud, F., Chapron, F., Desmet, M., Givelet, N., Alibert, C. and McCulloch, M., 2005: Sr and Nd isotopes as tracers of clastic sources in Lake Le Bourget sediment (NW Alps, France) during the Little Ice Age: Palaeohydrology implications. Chemical Geology 224, 183-200.

Richard, H. and Gauthier, E., 2007 : Bilan des données polliniques concernant l’âge du Bronze dans le Jura et le nord des Alpes. In Richard, H., Magny, M. and Mordant, C., editors, Environnements et cultures à l'âge du Bronze en Europe occidentale. Documents préhistoriques n² 21, Editions du CTHS, 71-87.

Rösch, M., 1998 : The history of crops and crop weeds in south-western Germany from the Neolithic period to modern times, as shown by archaeobotanical evidence. Vegetation History and Archaeobotany 7, 109-125.

Russell, G.B., Connor, H.E. and Purdie, A.W., 1976: Triterpene methyl ethers of Chinochloa (Gramineae). Phytochemistry 15, 1933-1935.

Sadori, L., Giraudi, C., Petitti, P. and Ramrath, A., 2004: Human impact at Lago di Mezzano (central Italy) during the Bronze Age: a multidisciplinary approach. Quaternary International 113, 5-17.

Schmidl, A. and Oeggl, K., 2005: Subsistence strategies of two Bronze Age settlements in the eastern Alps Friaga/Bartholomäberg (Vorarlberg, Austria) and Ganglegg/Scluderns (South Tyrol, Italy). Vegetation History and Archaeobotany 14, 303-312. 
Tinner, W., Lotter, A.F., Ammann, B., Conedera, M., Hubschmida, P., van Leeuwena, J.F.N. and Wehrli, M., 2003: Climatic change and contemporaneous land-use phases north and south of the Alps 2300 BC to 800 AD. Quaternary Science Reviews 22, 1447-1460.

Valsecchi, V., Tinner, W., Finsinger, W. and Amman, B., 2006: Human impact during the Bronze Age on the vegetation at Lago Lucone (northern Italy). Vegetation History and Archaeobotany 15, 99-113.

Wakeham, S. G., Schaffner, C. and Geiger, W., 1980: Polycyclic aromatic hydrocarbons in recent lake sediments - II. Compounds derived from biogenic precursors during early diagenesis. Geochimica et Cosmochimica Acta 44, 415-429.

Weber, S.A. and Fuller, D.Q.: Millets and their role in early agriculture. Pragdhara, in press.

Yunker, M.B. and Macdonald, R.W., 1995: Composition and origins of polycyclic aromatic hydrocarbons in the Mackenzie River and on the Beaufort Sea shelf. Arctic 48, 118-129.

Zohary, D. and Hopf, M., 1993: Domestication of plants in the old world. The origin and spread of cultivated plants in West Asia, Europe, and the Nile Valley. Clarendon Press, Oxford, pp. 328.

Zohary, D. and Hopf, M., 2000: Domestication of plants in the Old World, third edition. Oxford: University Press, pp 75.

Zolitschka, B., Behren, K.E. and Schneider, J., 2003: Human and climate impact on environment as derived from coluvial, fluvial and lacustrine archives - examples from the Bronze Age to Migration period, Germany. Quaternary Science Reviews 22, 81-100. 


\section{Table captions}

Table 1: ${ }^{14} \mathrm{C}$ dates used for the establishment of core LDB01 age model.

\begin{tabular}{|c|c|c|c|}
\hline Laboratory code & Depth $(\mathrm{cm})$ & ${ }^{14} \mathrm{C}$ age $( \pm 2 \sigma)$ & Median calibrated age $( \pm 2 \sigma)$ \\
\hline POZ 710 & 271 & $1200 \pm 30$ & $1010-1130-1230$ \\
\hline POZ 718 & 407 & $1800 \pm 30$ & $1570-1710-1860$ \\
\hline POZ 716 & 440.5 & $2250 \pm 30$ & $2150-2260-2340$ \\
\hline POS 717 & 619 & $3820 \pm 30$ & $4090-4200-4350$ \\
\hline POZ 715 & 667.5 & $4280 \pm 30$ & $4740-4840-4870$ \\
\hline POZ 721 & 791 & $5310 \pm 30$ & $5950-6080-6270$ \\
\hline
\end{tabular}

Table 2: ${ }^{14} \mathrm{C}$ and non- ${ }^{14} \mathrm{C}$ dates used for the establishment of core LDB04 age model.

\begin{tabular}{|c|c|c|c|c|c|c|c|}
\hline \multicolumn{8}{|c|}{ Non- ${ }^{14} \mathrm{C}$ age information } \\
\hline \multicolumn{3}{|l|}{ Historical event } & Core & Depth $(\mathrm{mm})$ & \multicolumn{2}{|c|}{$\begin{array}{l}\text { Age (yrs } \\
\text { AD) }\end{array}$} & Age (yrs cal. BP) \\
\hline \multirow{3}{*}{\multicolumn{3}{|c|}{$\begin{array}{l}\text { Chernobyl accident }\left({ }^{137} \mathrm{Cs}\right) \\
\text { Atmospheric bomb tests }\left({ }^{137} \mathrm{Cs} \text { and }\right. \\
\left.{ }^{241} \mathrm{Am}\right) \\
\text { Eutrophication }\end{array}$}} & LDB04-I & 20 & \multicolumn{2}{|c|}{1986} & -36 \\
\hline & & & LDB04-I & 50 & \multicolumn{2}{|c|}{1965} & -15 \\
\hline & & & LDB04-I & 80 & \multicolumn{2}{|c|}{1948} & 2 \\
\hline \multirow{2}{*}{\multicolumn{3}{|c|}{ Historical flood }} & LDB04-I & 190 & \multicolumn{2}{|c|}{1888} & 62 \\
\hline & & & LDBO4-I & 240 & \multicolumn{2}{|c|}{1888} & 62 \\
\hline \multicolumn{3}{|l|}{ Historical flood } & LDB04-I & 640 & \multicolumn{2}{|c|}{1734} & 216 \\
\hline \multicolumn{8}{|c|}{${ }^{14} \mathrm{C}$ age and calibration information } \\
\hline Laboratory code & Core & $\begin{array}{l}\text { Depth } \\
(\mathrm{mm})\end{array}$ & $\begin{array}{c}\text { Correlated } \\
\text { position on } \\
\text { LDB04-I (mm) } \\
\end{array}$ & \multicolumn{2}{|c|}{${ }^{14} \mathrm{C}$ Age $\pm 2 \sigma$} & \multicolumn{2}{|c|}{$2 \sigma$ mean cal Age (cal. BP) } \\
\hline Poz-13986 & LDB04-I & 1440 & - & 435 & \pm 30 & 495 & \pm 35 \\
\hline Poz-710 & LDB01-I & 2710 & 3350 & 1200 & \pm 30 & 1120 & \pm 110 \\
\hline Poz-13983 & LDB04-I & 3100 & - & 1665 & \pm 30 & 1570 & \pm 60 \\
\hline Poz-718 & LDB01-I & 4070 & 3810 & 1800 & \pm 45 & 1715 & \pm 145 \\
\hline Poz-716 & LDB01-I & 4405 & 2505 & 2250 & \pm 30 & 2245 & \pm 95 \\
\hline SacA4834 & LDB04-I & 4128 & - & 2770 & \pm 30 & 2870 & \pm 80 \\
\hline Poz-13984 & LDB04-I & 4480 & - & 2815 & \pm 30 & 2920 & \pm 80 \\
\hline Poz-13985 & LDB04-I & 4990 & - & 3300 & \pm 30 & 3525 & \pm 65 \\
\hline Poz-10562 & LDB04-I & 5810 & - & 4160 & \pm 35 & 4160 & \pm 60 \\
\hline Poz-14033 & LDB04-I & 6960 & - & 4640 & \pm 35 & 5385 & \pm 85 \\
\hline Poz-721 & LDB01-I & 7910 & 7500 & 5310 & \pm 40 & 6110 & \pm 160 \\
\hline Poz-14032 & LDB04-I & 7770 & - & 5870 & \pm 40 & 6690 & \pm 70 \\
\hline Poz-10563 & LDB04-I & 8400 & - & 6610 & \pm 40 & 7505 & \pm 45 \\
\hline Poz-13987 & LDB04-I & 9440 & - & 8080 & \pm 40 & 9015 & \pm 235 \\
\hline SacA4836 & LDB04-I & 10835 & - & 8655 & \pm 45 & 9615 & \pm 85 \\
\hline SacA4835 & LDB04-I & 9875 & - & 8720 & \pm 50 & 9695 & \pm 145 \\
\hline SacA4837 & LDB04-I & 11655 & - & 9320 & \pm 35 & 10500 & \pm 100 \\
\hline Poz-10565 & LDB04-I & 12180 & - & 9450 & \pm 50 & 10695 & \pm 85 \\
\hline Poz-10566 & LDB04-I & 12940 & - & 9490 & \pm 50 & 10850 & \pm 170 \\
\hline
\end{tabular}




\section{Figure captions}

Figure 1: Location of Lake le Bourget (French Alps) and coring sites (LDB01 and LDB04). The grey arrow indicates the trajectory of Rhône River waters during floods, over the Savière canal and the Chautagne swamp. Numerous archaeological sites have been identified on the lakeshore such as Tresserve and Grésine, discussed in the text.

Figure 2: Structure of (a) miliacin (olean-18-en-3ßol ME) and (b) 3,3,7-trimethyl-1,2,3,4tetrahydrocrysene (TTHC).

Figure 3: Age models of cores LDB01 and LDB04 established from ${ }^{14} \mathrm{C}$ dates, radiometric markers for the historical period, lake eutrophication in 1948, and catastrophic floods. The stratigraphic position of some ${ }^{14} \mathrm{C}$ dates measured on core LDB01 have been reported on core LDB04 by comparing the magnetic susceptibility and colour measurements performed at a $5 \mathrm{~mm}$ sampling step on both cores

Figure 4: Evolution of titanium, miliacin and TTHC during the last 8000 yrs in the sediments of Lake le Bourget (core LDB04). Due to erroneous calculation in some levels, miliacin concentrations have been recalculated from Jacob et al. (2008).

Figure 5: Compared evolution of miliacin and TTHC in cores LDB04 and LDB01 for the 2200/500 BC period.

Figure 6: Comparison of the evolution of miliacin and titanium in deep core LDB04 with the evolution of forest pollen (Fagus), Cerealia type pollens, Poaceae and other anthropogenic pollen indicators (footpath, ruderal and weed communities) retrieved from the Tresserve archaeological site, on the eastern Lake le Bourget shore. 
Figure 1

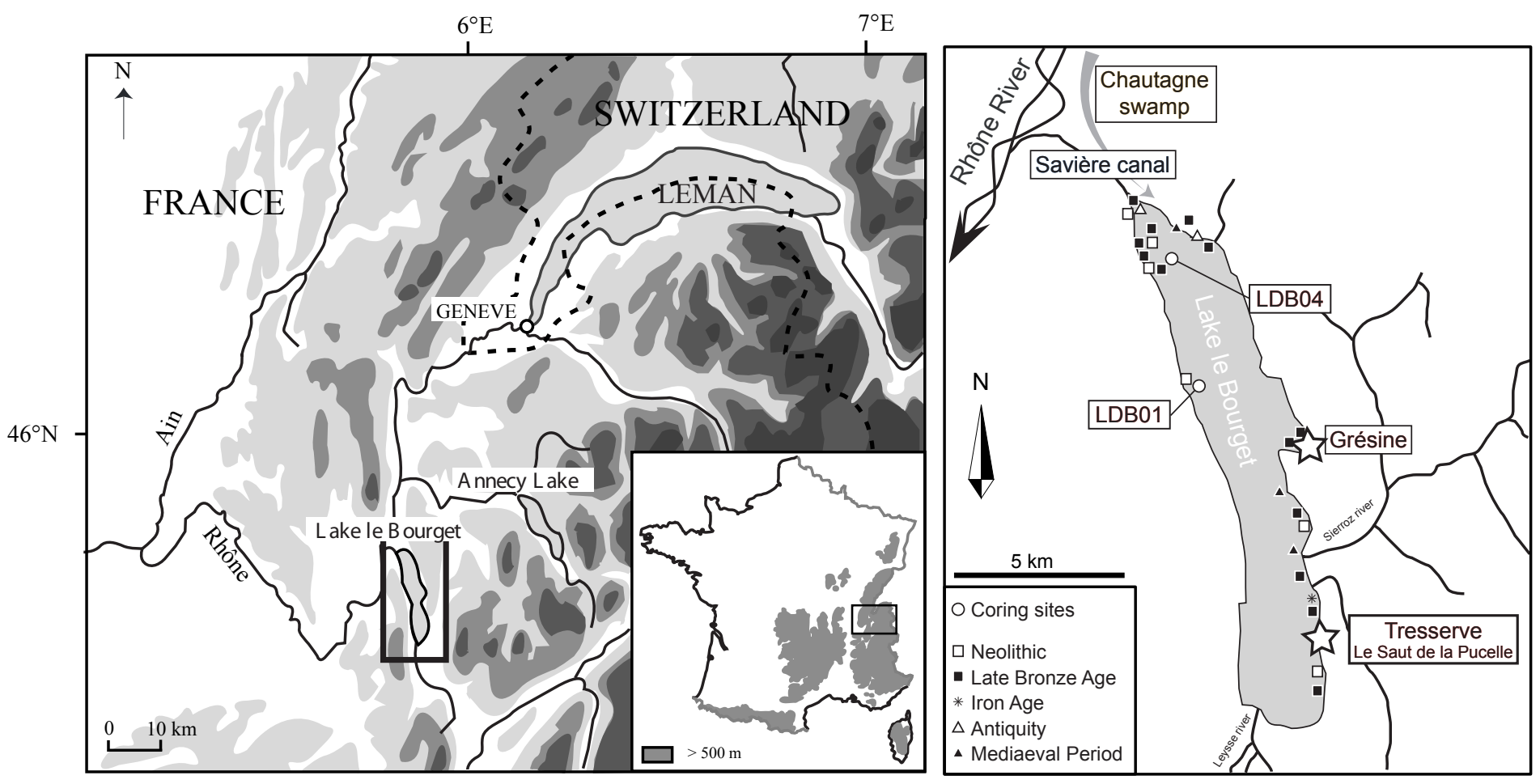

$500-1000$ m

$1000-1500 \mathrm{~m}$

$1500-2000 \mathrm{~m}$

$>2000 \mathrm{~m}$ 
Figure 2
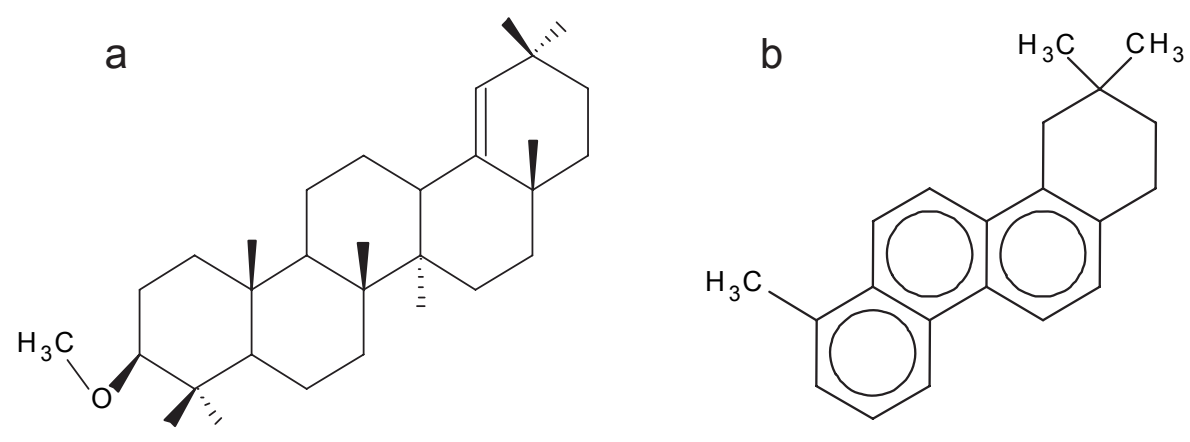
Figure 3

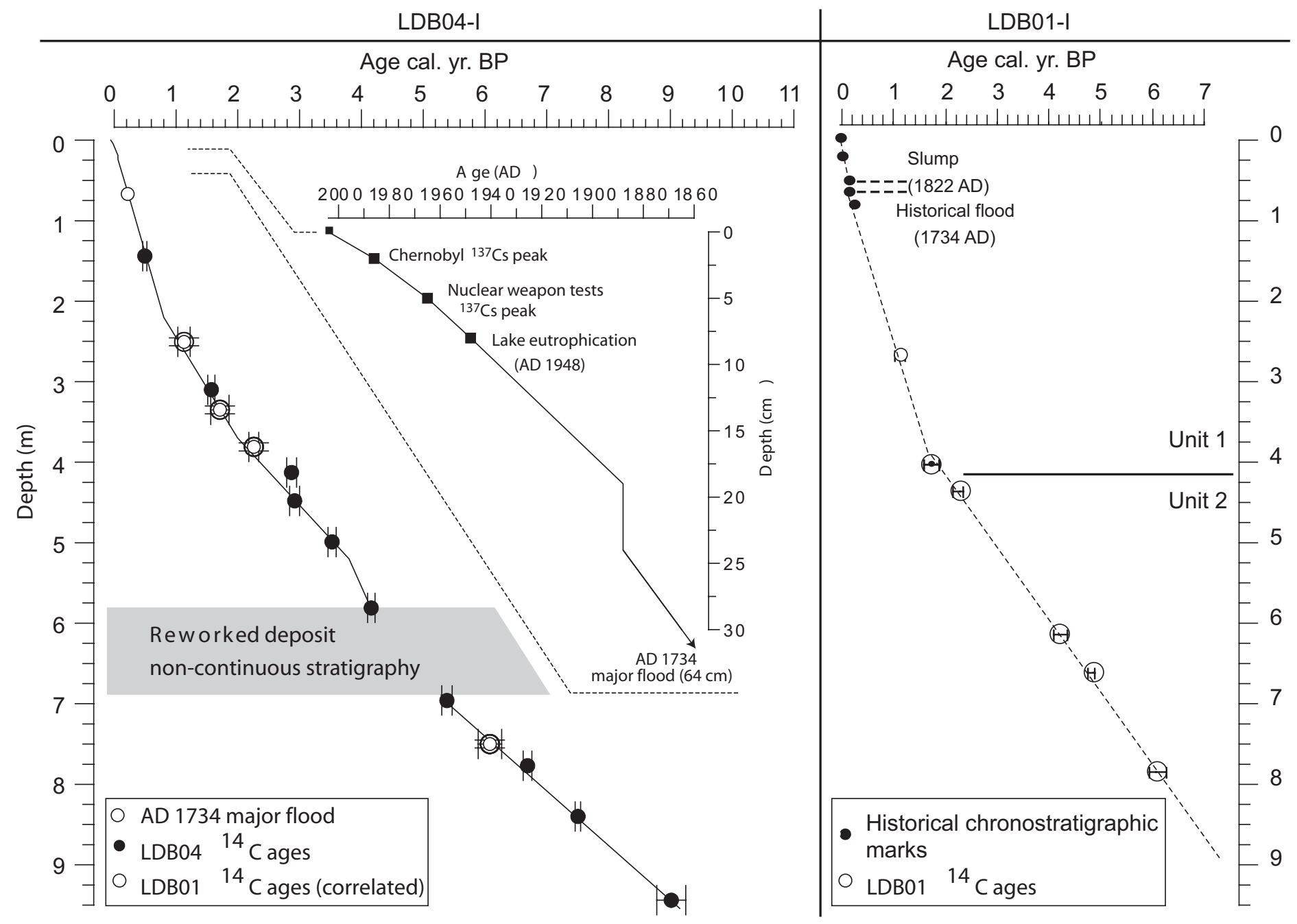


Figure 4

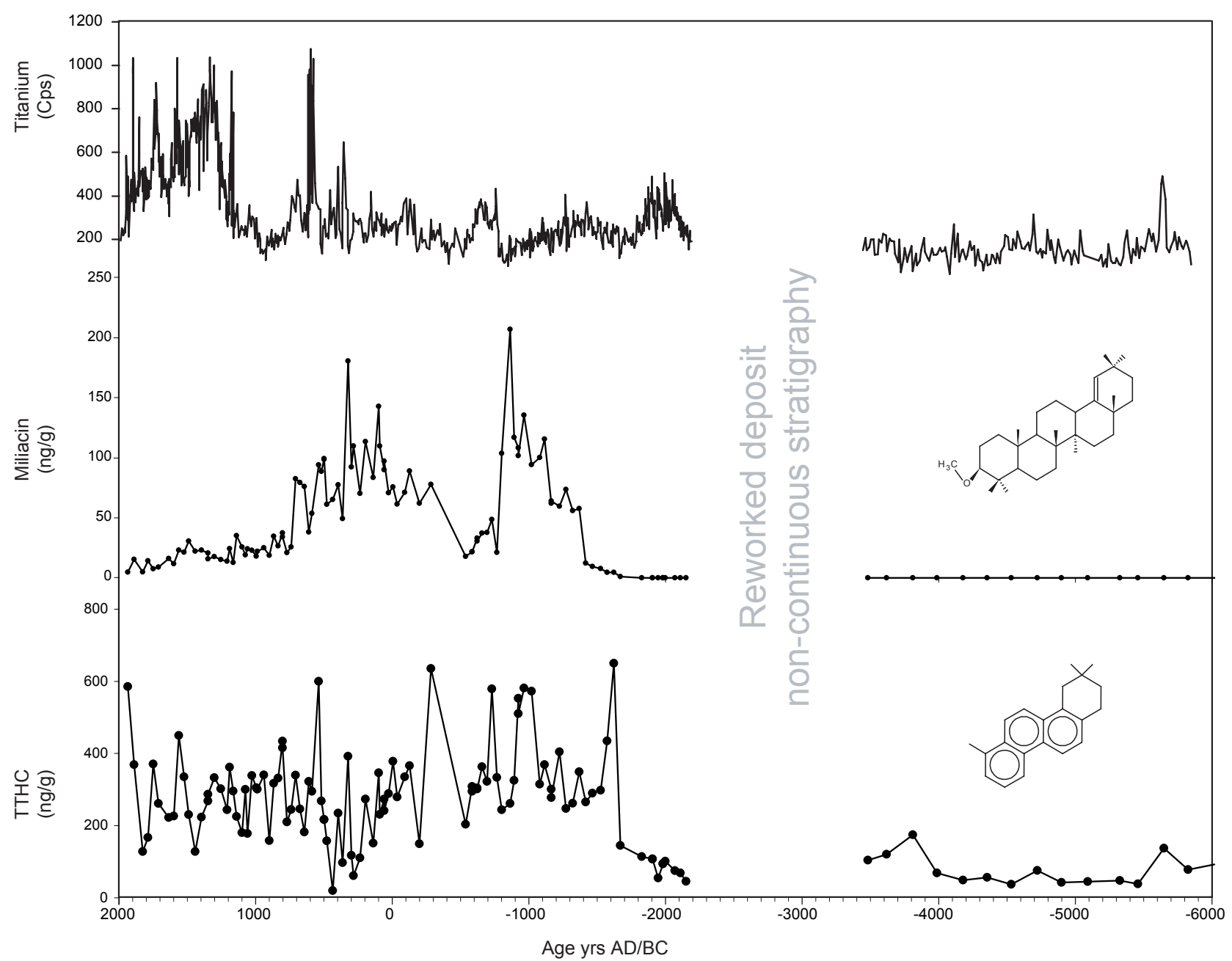


Figure 5

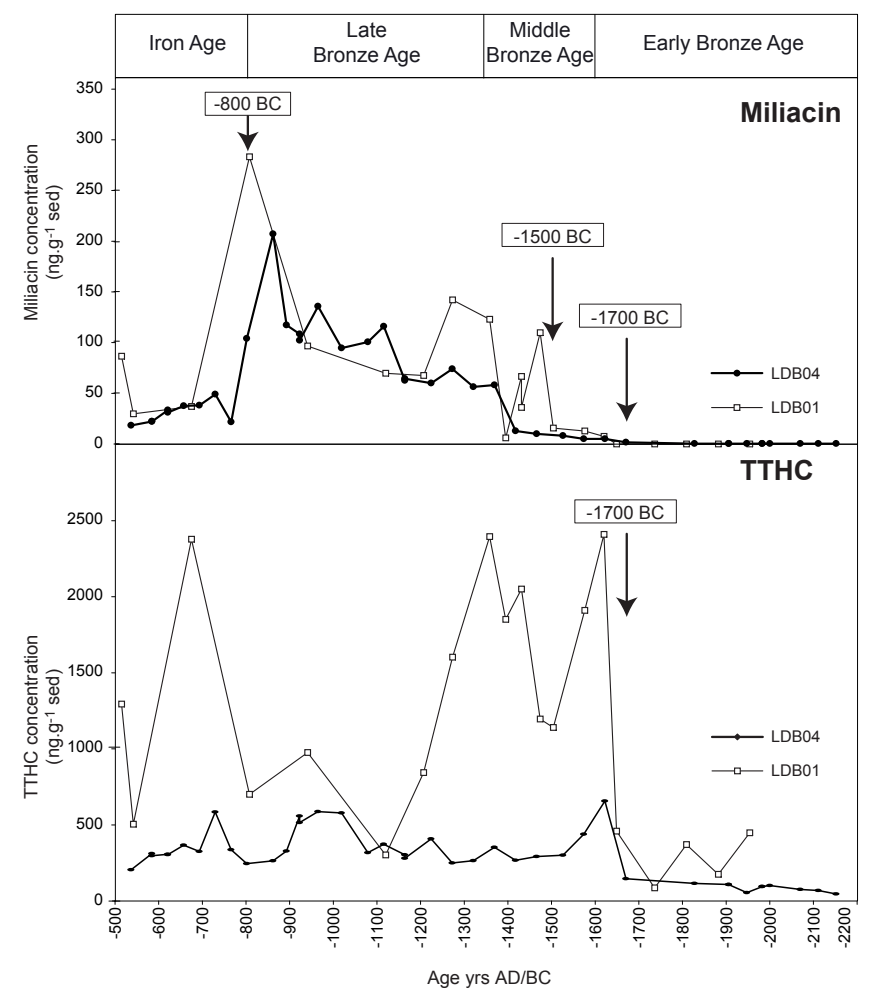


Figure 6

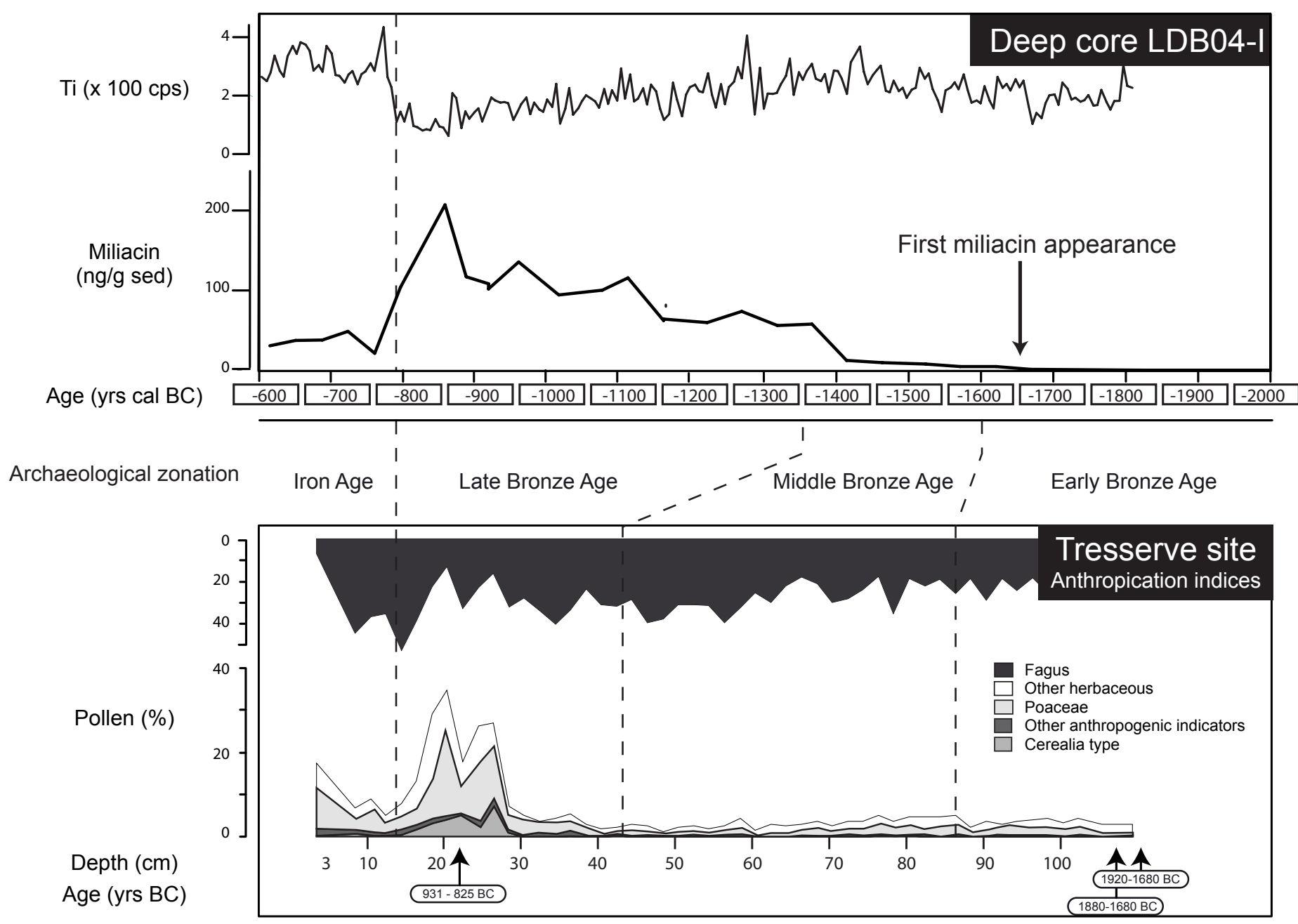

